\title{
Upaya Meminimalisir Kenakalan Siswa Melalui Identifikasi Sebab pada Kelas XI SMA Negeri Woja Kabupaten Dompu Tahun 2018/2019
}

\author{
Putri Emilia \\ Guru SMA Negeri 1 Woja, Kabupaten Dompu, Nusa Tenggara Barat \\ E-mail: purtriemiliasma1woja@gmail.com
}

Article History: Received: 2020-09-14 || Revised: 2020-10-02 || Published: 2020-10-26

Sejarah Artikel : Diterima: 2020-09-14 || Direvisi: 2020-10-02 || Dipublikasi: 2020-10-26

\begin{abstract}
This research is a classroom action research using qualitative research methods. The research location was carried out at SMA Negeri 1 Woja, namely in Class XI. Data collection was carried out by observation, documentation, and interviews. The results of this study are: 1) Efforts to raise expectations for both short and long term impacts if students are good, close to teachers, and able to communicate in an attractive style, and are able to achieve, 2) Guidance on how to seek the attention of the opposite sex and school colleagues by empathic communication strategy and not violating the norms of decency, 3) The strategy of working with religious teachers to instill religious values through light discussions between student-teachers (not lectures), 4) Conditioning the fulfillment of the needs of self-existence and giving pleasure, by activating students in extracurricular organizations that they like, such as sports, music, etc., 5) Providing guidance on the analysis of the impact of bad actions, the impact of indulging unfulfilled biological desires, and continued with a strategy guide to shifting attention to biological needs with positive activities, 6) Providing leadership guidance to gain power, by assigning students to enter into positive group activities such as music, sports, or others, 7) Fostering independence to address economic needs ., 8) Fostering conflict resolution in a win-win solution (win and win), 9) Additional actions are taken by sharing with the family.
\end{abstract}

Keywords: Delinquency, Youth, Identification of causes.

\begin{abstract}
Abstrak
Penelitian adalah penelitian tindakan kelas, dengan motode penelitian kualitatif. Lokasi penelitian terlaksana di SMA Negeri 1 Woja yaitu di Kelas XI. Pengambilan data dilakukan dengan observasi, dokumentasi, dan wawancara.Hasil penelitian adalah: 1) Upaya menumbuhkan harapan akan dampak baik jangka pendek dan panjang jika siswa bersikap baik, dekat dengan guru, serta mampu berkomunikasi dengan gaya yang memikat, serta mampu berprestasi, 2) Bimbingan cara mencari perhatian lawan jenis dan rekan sekolah dengan strategi komunikasi yang empatik dan bukan dengan cara pelanggaran norma kesusilaan, 3) Strategi bekerjasama dengan guru agama untuk menanamkan nilai-nilai religious dengan cara diskusi ringan antara siswa-guru (bukan menceramahi), 4) Mengkondisikan terpenuhinya kebutuhan eksistensi diri serta memberikan kesenangan, dengan mengaktifkan siswa pada organisasi-organisasi ekstrakurikuler yang disenangi seperti bidang olah raga, music, dan lainnya, 5) Memberikan bimbingan analisis dampak dari suatu tindakan buruk, dampak dari mengumbar hasrat biologis yang belum waktunya dipenuhi, dan dilanjutkan dengan bimbingan strategi mengalihkan perhatian dari kebutuhan biologis dengan kegiatan positif, 6) Memberikan bimbingan kepemimpinan untuk mendapatkan power kekuasaan, yang dengan penugasan pada siswa untuk masuk pada kelompok kegiatan positif seperti music, olah raga, atau lainnya, 7) Bimbingan kemandirian untuk mengatasi kebutuhan ekonomi., 8) Bimbingan resolusi konflik secara win-win solution (menang sama menang), 9) Tindakan tambahan dilakukan dengan melakukan sharing dengan pihak keluarga.
\end{abstract}

Kata kunci: Kenakalan, Remaja, Identifikasi sebab.

\section{PENDAHULUAN}

Masa remaja adalah masa krisis identitas bagi kebanyakan anak remaja. Remaja sedang mencari-cari figur panutan, namun figur itu tidak ada didekatnya. Secara umum dan dalam kondisi normal sekalipun, masa ini merupakan periode yang sulit untuk ditempuh, baik secara individual 
ataupun kelompok, sehingga remaja sering dikatakan sebagai kelompok umur bermasalah (the trouble teens)

Di kalangan siswa saat ini banyak terjadi berbagai perilaku yang menyimpang, yang secara umum dianggap tidak normatif dan membawa dampak buruk bagi dirinya sendiri maupun orang lain. Sebagaimana ditayangkan di berbagai media elektronik, sering dijumpai pemberitaan tentang keterlibatan siswa yang masih remaja dalam sex bebas, tawuran antar siswa sekolah, tindak pemerasan pada siswa yang dianggap lemah, pelecehan sexual, bahkan di media internet banyak dijumpai video-video porno yang dibuat dan dilakukan oleh siswa remaja berseragam sekolah. Disamping kenakalan-kenakalan remaja yang dapat dianggap sebagai kenakalan dalam tingkatan yang berat, masih banyak kenakalan remaja yang sifatnya ringan sampai sedang, yang dianggap sebagai bentuk kenakalan klasik bagi siswa, seperti pelanggaran tata tertib sekolah yang meliputi tindakan bolos sekolah, corat-coret, tidak tertib dalam berseragam, gaduh, dan lainnya.Hal tersebut yang menjadi salah satu sebab mengapa masa remaja dinilai lebih rawan daripada tahap-tahap perkembangan manusia yang lain. Dalam rangka menanggulangi kenakalan remaja di sekolah, dapat dilakukan berbagai upaya oleh guru sekolah, khususnya guru yang terkait dengan bimbingan konseling. Salah satu upaya tersebut adalah upaya Meminimalisir, menanggulangi kenakalan maupun kejahatan melalui identifikasi sebab-sebab Pemicukemunculannya (Sudarsono, 2004: 11).

SMA Negeri 1 Woja Kabupaten Dompu merupakan sekolah yang juga tak lepas dari berbagai kendala dalam pelaksanaan pendidikan, seperti kendala yang berupa kenakalan remaja. Berdasarkan catatan-catatan tentang penyimpangan perilaku siswa yang dikatogorikan sebagai kenakalan remaja, pada tahun 2017 terdapat sekitar $10 \%$ siswa Kelas XI yang melakukan tindak kenakalan, dimana 2\% dianataranya adalah siswi (perempuan). $3 \%$ dari kenakalan tersebut berupa kenakalan ringan, 3\% beruapa kenakalan sedang, dan 2\% lainnya adalah kenakalan berat. Angka kenakalan remaja tersebut dirasa harus diwaspadai agar tidak meningkat, bahkan harus mengalami penurunan, sebab cukup banyak memberikan gangguan pada pelaksanaan proses pendidikan di sekolah, yaitu berupa gangguan kenyamanan pada siswa lain yang sedang belajar di sekolah, gangguan penundaan proses pembelajaran di kelas, gangguan yang berupa penurunan kualitas hasil belajar siswa rata-rata di kelas, gangguan yang berupa pengaruh kepada siswa lain untuk mengikuti tindak kenakalan, serta gangguan-gangguan lainnya yang berdampak pada melemahnya kualitas hasil belajar siswa secara umum di sekolah. Kelas XI tersebut merupakan kelas dengan tingkat kenakalan remaja tertinggi dibanding dengan siswa kelas X dan XII.

Berdasarkan atas uraian tersebut, maka dirasa perlu untuk dilaksanakan penelitian tindakan dalam rangka memperoleh temuan tindakan yang terbaik dan paling sesuai dengan kondisi siswa dan sekolah, dengan judul "Upaya Meminimalisir Kenakalan Siswa Melalui Identifikasi SebabSebab Pemicu Kemunculannya Sebagai Cara Yang Sangat Efektif Pada Kelas XI SMA Negeri 1 Woja tahun 2018/2019." Tujuan dari dilaksanakannya penelitian ini adalah untuk mengetahui hal-hal sebagai berikut: (1)Langkah-langkah yang dilakukan untuk mengurangi kenakalan siswa kelas XI SMA Negeri 1 Woja Kabupaten Dompu dengan cara Meminimalisir Kenakalan Siswa Melalui Identifikasi Sebab-Sebab PemicuKemunculannya Sebagai Cara Yang Sangat Efektif Pada Kelas XI SMA Negeri 1 Woja tahun 2018/2019 (2) Besarnya penurunan angka kenakalan siswa kelas XI yang dapat dicapai dengan cara Meminimalisir Kenakalan Siswa Melalui Identifikasi Sebab-Sebab Pemicu Kemunculannya Sebagai Cara Yang Sangat Efektif Pada Kelas XI SMA Negeri 1 Woja tahun Pembelajaran 2018/2019.

\section{METODE PENELITIAN}

Penelitian dilaksanakan di kelas XI SMA Negeri 1 Woja. Sasaran penelitian adalah semester I tahun pembelajaran 2018/2019. Perubahan yang hendak dicapai dalam penelitian ini adalah turunnya tingkat kenakalan remaja di kelas XI SMA Negeri 1 Woja Kabupaten Dompu dengan tidak 
memberikan dampak yang buruk pada perkembangan kejiwaan anak seperti dampak seperti dendam karena hukuman, dampak menurunnya minat belajar di sekolah, dan dampak lainnya. Adapun Pendekatan penelitian ini adalah penelitian tindakan kelas (PTK) yaitu suatu studi sistematis terhadap tindakan pembelajaran di kelas untuk menemukan tindakan terbaik sebagai bentuk perbaikan proses pembelajaran dan hasil belajar siswa, melalui penerapan tindakan untuk mengurangi kenakalan remaja pada siswa kelas XI SMA Negeri 1 Woja Kabupaten Dompu.

Prosedur penelitian yang digunakan adalah prosedur siklus, dengan metode penelitian deskriptif kualitatif. Prosedur siklus merupakan prosedur pelaksanaan penelitian yang dilakukan dengan beberapa tahapan yang sama, dimana pada tahap selanjutnya dilakukan untuk memperbaiki tindakan pada tahap sebelumnya. Sementara itu, metode deskriptif kualitatif merupakan metode penelitian yang dilakukan dengan menggambarkan kondisi yang ada sesuai dengan realita yang ada secara rinci dan ilmiah dengan analisis tekstual (non matematis). Rancangan penelitian tindakan kelas yang dilakukan adalah dengan prosedur siklus yang dilakukan dengan dua tahapan atau siklus, yang setiap siklusnya dilakukan melalui tahap perencanaan, tindakan, observasi, dan refleksi. Hasil refleksi siklus I akan menjadi bahan pertimbangan untuk perencanaan pada siklus berikutnya, sedangkan hasil refleksi dalam siklus II sebagai siklus terakhir menjadi bahan untuk penarikan kesimpulan.

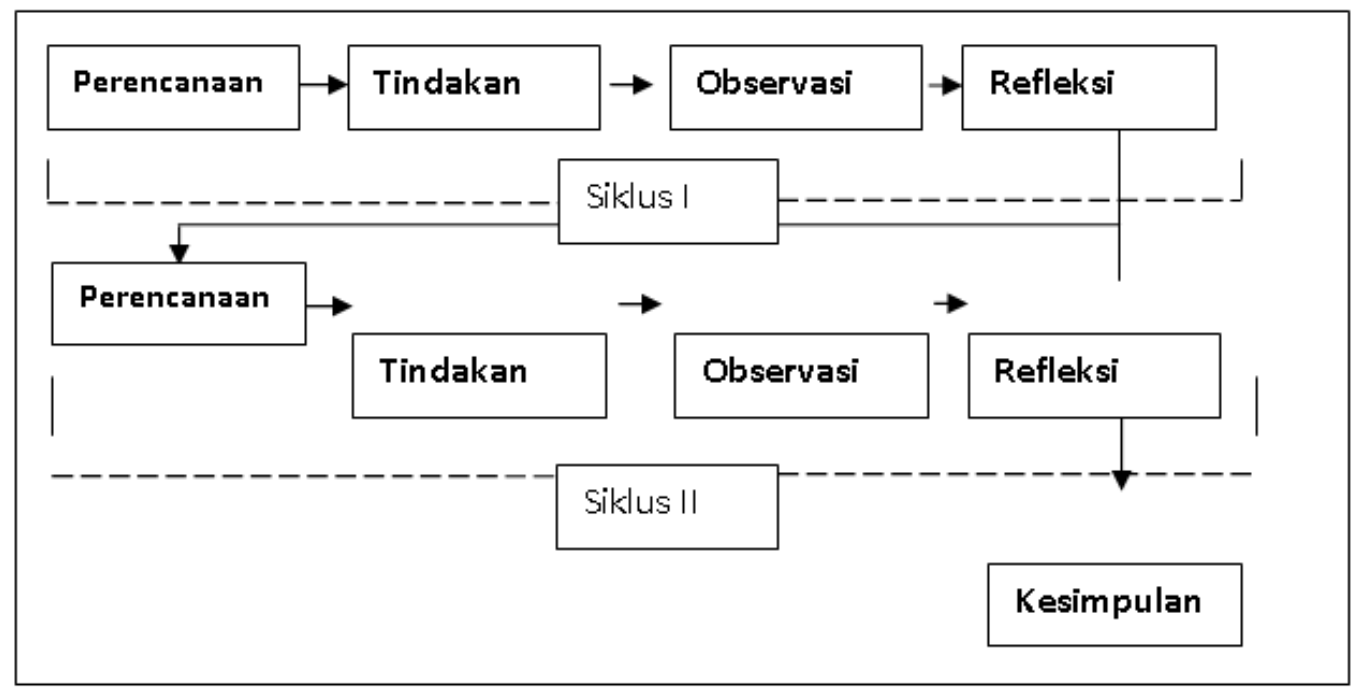

Gambar 1. Siklus Penelitian Tindakan Kelas (PTK)

Pengumpulan data dilakukan dengan Observasi, tes, wawancara mendalam dan dokumentasi. Analisis data dilakukan dengan metode kualitatif, dimana data yang dihimpun disusun secara sistematis kemudian diinterprestasikan dan dianalisis sehingga dapat menjelaskan pengertian dan pemahaman tentang gejala yang diteliti. Pada penelitian ini menggunakan metode analisis model interaktif, dengan empat komponen pokok dalam proses analisis data, yaitu reduksi data, sajian data, penarikan dan kesimpulan/verifikasi.

\section{HASIL DAN PEMBAHASAN}

\section{A. Hasil Penelitian}

\section{Kondisi Pra Pelaksanaan Penelitian}

Sebelum dilaksanakannya penelitian tindakan, dilakukan observasi pendahuluan terhadap kondisi kenakalan remaja yang terjadi pada siswa kelas XI SMA Negeri 1 Woja yang meliputi bentuk-bentuk kenakalan remaja yang muncul dan intensitas kemunculannya. Untuk mengukur intensitas kenakalan yang muncul, dihitung dengan frekwensi kejadian per minggu, yang selanjutnya dilakukan scoring dengan kriteria sebagai berikut: 
Jumlah kejadian terbanyak yang ditemui: 20 Kali

Jumlah kejadian paling sedikit yang ditemui: 1 kali

Range $=20-1=19$

Dalam penelitian ini, jumlah skor yang diambil adalah $1-4$, sehingga interval yang digunakan adalah $19 / 4=4,8$ atau 5 , sehingga range skor yang digunakan adalah seperti pada tabel Berikut:

Tabel 1. Kriteria intensitas Kenakalan Remaja Siswa Kelas XI

\begin{tabular}{|c|c|c|}
\hline No & Frekuensi Kejadian/bulan & Skor \\
\hline 1 & 1-5 Kali & 1 \\
\hline 2 & 6-10 Kali & 2 \\
\hline 3 & 11-15 Kali & 3 \\
\hline 4 & 16-20 Kali & 4 \\
\hline
\end{tabular}

Berdasarkan atas tabel kriteria scoring yang telah dibuat, dapat dilakukan scoring tingkat kenakalan remaja pada siswa kelas XI berdasarkan hasil observasi seperti pada table sebagai berikut:

Tabel 2. Bentuk-Bentuk Kenakalan Remaja Pada Siswa

\begin{tabular}{lccc}
\hline No & Bentuk Kenakalan & $\begin{array}{c}\text { Rerata } \\
\text { Kejadian } \\
\text { Perbulan }\end{array}$ & Skor \\
& & \\
\hline
\end{tabular}

Kenakalan Berupa Pelanggaran Norma Kesusilaan dan Tata Tertib Sekolah

\begin{tabular}{|c|c|c|c|}
\hline 1 & Membolos dan kabur dari jam pelajaran & 2 kali & 1 \\
\hline 2 & $\begin{array}{l}\text { Berkelompok dan berlaku iseng pada lawan jenis seperti } \\
\text { mencolek. }\end{array}$ & 5 kali & 1 \\
\hline 3 & $\begin{array}{l}\text { Berkelompok dan melakukan aktivitas yang tidak tertib } \\
\text { (ribut, gaduh, menimbulkan ketakutan) }\end{array}$ & 5 kali & 1 \\
\hline 4 & $\begin{array}{l}\text { Melihat hal-hal yang bersifat cabul melalui handphone dan } \\
\text { lainnya }\end{array}$ & 6 kali & 2 \\
\hline 5 & $\begin{array}{l}\text { Penggunaan bahasa kasar yang melanggar kesusilaan pada } \\
\text { teman sekolah. }\end{array}$ & 20 kali & 4 \\
\hline 6 & $\begin{array}{l}\text { Berpakaian tidak rapi sebagaimana tata tertib yang } \\
\text { ditentukan. }\end{array}$ & 15 kali & 3 \\
\hline 7 & Merokok di lingkungan sekolah. & 7 kali & 2 \\
\hline 8 & $\begin{array}{l}\text { Berani pada guru saat proses pembelajaran seperti } \\
\text { menentang perintah guru atau menggunakan bahasa yang } \\
\text { tidak sopan. }\end{array}$ & 3 kali & 1 \\
\hline 9 & Aksi corat-coret dinding sekolah & 2 kali & 1 \\
\hline 10 & Menyontek saat ulangan & 7 kali & 2 \\
\hline \multicolumn{4}{|c|}{ Kenakalan Berupa Pelanggaran Hukum } \\
\hline 1 & Perkelahian didalam ataupun diluar sekolah & 1 kali & 1 \\
\hline 2 & Miras dan Narkoba & 1 kali & 1 \\
\hline 3 & $\begin{array}{l}\text { Pelecehan sexual tingkat ringan yang belum sampai pada } \\
\text { tahap pemerkosaan }\end{array}$ & 1 kali & 1 \\
\hline 4 & Tindak pemerasan & 3 kali & 1 \\
\hline 5 & $\begin{array}{l}\text { Tindak pemaksaan yang berupa memaksa teman untuk } \\
\text { mengikuti kehendaknya dengan cara mengancam }\end{array}$ & 6 kali & 2 \\
\hline
\end{tabular}




\begin{tabular}{|c|c|}
\hline Tindak penipuan & 1 kali \\
\hline Rata-Rata & 5,6 (atau 7 kali) \\
\hline
\end{tabular}

Berdasarkan hasil observasi pra penelitian tindakan tersebut, terlihat bahwa rata-rata skor kejadian tindak kenakalan remaja di sekolah adalah 2 atau dalam intensitas sedang. Meskipun demikian, terdapat satu kejadian ekstrim dimana jumlah kejadian kenakalan mencapai 20 kali per bulan yaitu pada penggunaan bahasa yang kasar yang biasa digunakan siswa. Hal ini tidak dapat didiamkan, sebab salah satu fungsi penddidikan adalah membentuk siswa yang berbudi luhur. Penelitian tindakan kelas ini diharapkan paling tidak mampu mengurangi jumlah kejadian tindak kenakalan remaja yang ekstrim dan mampu menurunkan jumlah tindak kenakalan remaja secara keseluruhan.

\section{Pelaksanaan Siklus I}

Tindakan dalam penelitian ini dilaksanakan sesuai dengan rencana pelaksanaan penelitian sesuai dengan penyebab terjadinya tindak kenakalan remaja yang muncul. Pada prinsipnya, tindakan penelitian dilaksanakan melalui tiga jalur:

\section{a) Jalur bimbingan melalui pembelajaran didalam kelas.}

Jalur bimbingan melalui pembelajaran BK didalam kelas dilaksanakan yang terkait dengan hal-hal yang bersifat konseptual dan dasar-dasar pengetahuan yang penting bagi siswa. Jalur yang ditempuh melalui bimbingan dalam kelas ini diantaranya adalah:

a. Bimbingan motivasi

b. Menunjukkan pada siswa tentang bagaimana cara positif mencari perhatian lawan jenis

c. Memberi bimbingan bahwa kebutuhan biologis akan dapat dicapai pada waktunya nanti, dan memberi pengetahuan tentang dampak buruk dalam berlebihan memenhi kebutuhan biologis, yang diikuti dengan bimbingan untuk memberi motivasi siswa untuk menemukan kegiatan positif seperti melalui music atau olah raga.

d. Memberi bimbingan tentang membiasakan memandang dari kacamata pihak lain, sehingga siswa memahami dampak perbuatannya dimata orang lain.

e. Memberikan bimbingan strategi merebut empati orang lain sehingga power yang dimilikinya dengan sendirinya akan muncul,

f. Memberi bimbingan tentang bagaimana langkah yang paling tepat untuk mendapat perhatian melalui strategi praktis berkomunikasi (mendengarkan pembicaraan, empatik, humor, gemar memberikan alternative solusi pada masalah orang lain), strategi prestasi pada bidang tertentu, strategi bersosial.

g. Memberi bimbingan tentang arti penting dan manfaat tata tertib sekolah.

h. Memberi bimbingan tentang bagaimana cara agar siswa mendapat pengakuan kedewasaan dengan cara positif, seperti dengan berperan dan menunjukkan kemampuan dalam bidang kelompok humoris, olah raga, music, atau hal positif lainnya.

i. Meberikan bimbingan tentang dampak buruk yang luas akibat berani pada orang lain termasuk guru.

j. Memberikan bimbingan tentang cara memperoleh simpatik dari guru sehingga rasa benci berubah menjadi suka setelah mendapat simpatik dari guru, melalui sikap berani tampil didepan kelas, aktif dalam kegiatan diskusi kelas, aktif berkomunikasi dengan guru didalam dan diluar sekolah

k. Memberikan bimbingan tentang bagaimana cara menunjukkan eksistensi dan keunggulan kelompok

l. Memberikan bimbingan resolusi konflik yang mengarah pada win-win solution (menang sama menang), 
m. Menunjukkan cara inovatif dala menunjukkan eksistensi diri dan kelompok seperti bertanding skill secara fair.

n. Memberikan harapan pada masa depan dan memikirkan dampak buruk pada masa depan anak melalui studi kasus penggunaan miras dan narkoba.

o. Menunjukkan trik dan tips menghindari penggunaan narkoba.

p. Memberikan bimbingan tentang analisis kebutuhan melalui skala prioritas pemebuhan kebutuhan untuk mengendalikan kebutuhan yang kurang baik atau berat terpenuhi.

q. Memberikan bimbingan teknik komunikasi

\section{b) Jalur bimbingan khusus di ruangan BK}

Tindakan pada jalur ini dilakukan seiring dengan munculnya kasus, yang mana tindakan ini juga dapat berupa pengulangan dari jalur bimbingan dalam kelas yang lebih diperdalam di ruangan khusus,

\section{c) Jalur Diluar Bimbingan Siswa}

Jalur ini ditempuh ketika sebab dari munculnya masalah adalah kondisi tidakadanya pembinaan atau pendidikan didalam dilngkungan rumah tangga, yang dilakukan dengan berdialog dengan orang tua siswa, melakukan kerjasama dengan guru dan kepala sekolah untuk pada langkah mengupayakan terjadinya perhatian positif, empatik dalam mengajar, dan motivasi secara khusus pada siswa nakal, memberikan motivasi sehingga siswa berubah sikap dengan guru. Setelah dilaksanakannya strategi bimbingan tersebut oleh guru BK maka respon siswa, serta kendala-kendala yang muncul, Tingkat kenakalan remaja pada siswa kelas XI menurun drastis pada siklus 1 sebagai berikut:

Tabel 3. Hasil observasi Bentuk-Bentuk Kenakalan Remaja Pada Siklus I

\begin{tabular}{|c|c|c|c|}
\hline No & Bentuk Kenakalan & $\begin{array}{c}\text { Rata-Rata } \\
\text { Kejadian per } \\
\text { bulan }\end{array}$ & Skor \\
\hline \multicolumn{4}{|c|}{ Kenakalan Berupa Pelanggaran Norma Kesusilaan dan Tata Tertib Sekolah } \\
\hline 1 & Membolos dan kabur dari jam pelajaran & 0 kali & 0 \\
\hline 2 & $\begin{array}{l}\text { Berkelompok dan berlaku iseng pada lawan jenis } \\
\text { seperti mencolek. }\end{array}$ & 2 kali & 1 \\
\hline 3 & $\begin{array}{l}\text { Berkelompok dan melakukan aktivitas yang tidak } \\
\text { tertib (ribut, gaduh, menimbulkan ketakutan) }\end{array}$ & 2 kali & 1 \\
\hline 4 & $\begin{array}{l}\text { Melihat hal-hal yang bersifat cabul melalui } \\
\text { handphone dan lainnya }\end{array}$ & 3 kali & 1 \\
\hline 5 & $\begin{array}{l}\text { Penggunaan bahasa kasar yang melanggar } \\
\text { kesusilaan pada teman sekolah. }\end{array}$ & 7 kali & 2 \\
\hline 6 & $\begin{array}{l}\text { Berpakaian tidak rapi sebagaimana tata tertib } \\
\text { yang ditentukan. }\end{array}$ & 7 kali & 2 \\
\hline 7 & Merokok di lingkungan sekolah. & $5 \mathrm{kali}$ & 1 \\
\hline 8 & $\begin{array}{l}\text { Berani pada guru saat proses pembelajaran seperti } \\
\text { menentang perintah guru atau menggunakan } \\
\text { bahasa yang tidak sopan. }\end{array}$ & 0 kali & 0 \\
\hline 9 & Aksi corat-coret dinding sekolah & $1 \mathrm{kali}$ & 1 \\
\hline 10 & Menyontek saat ulangan & 4 kali & 1 \\
\hline \multicolumn{4}{|c|}{ Kenakalan Berupa Pelanggaran Hukum } \\
\hline 1 & Perkelahian didalam ataupun diluar sekolah & 0 kali & 0 \\
\hline \multirow[t]{2}{*}{2} & Miras dan Narkoba & $1 \mathrm{kali}$ & 1 \\
\hline & $\begin{array}{l}\text { Pelecehan sexual tingkat ringan yang belum } \\
\text { sampai pada tahap pemerkosaan }\end{array}$ & 0 kali & 0 \\
\hline
\end{tabular}




\begin{tabular}{clcc}
\hline 3 & Tindak pemerasan & 1 kali & 1 \\
\hline 4 & $\begin{array}{l}\text { Tindak pemaksaan yang berupa memaksa teman } \\
\text { untuk mengikuti kehendaknya dengan cara } \\
\text { mengancam }\end{array}$ & 3 kali & 1 \\
\hline 5 & Tindak penipuan & 0 kali & 0 \\
\hline Rata-Rata & $\begin{array}{c}2,4 \text { kali } \\
\text { (atau 2 kali) }\end{array}$ & 1 \\
\hline
\end{tabular}

Berdasarkan hasil observasi tersebut, terlihat bahwa rata-rata kejadian terjadinya tindak kenakalan remaja turun dari 5,6 menjadi 2,4, dengan skor intensitas turun dari 2 menjadi 1 atau dari intensitas sedang menjadi rendah. Berdasarkan atas temuan dalam observasi, dibuat refleksi tindakan yang perlu dilakukan yaitu Dilakukan bimbingan lanjutan pada siklus II pada aspek-aspek yang sama pada siklus I, dengan perbaiakn-perbaiakn sebagai berikut:

a. Dilakukan pelatihan praktis strategi merebut perhatian rekan sesame dan lawan jenis dengan teknik mendengarkan secara empatik, kegiatan praktis berlatih menyarankan dengan cara yang menyenangkan yaitu dengan menunjukkan dampak positif yang sangat didambakan teman terlebih dahulu yang dikaitkan dengan saran yang akan diberikan, kegiatan praktis melatih sense of humor (dengan mengaitkan pembicaraan pada hal-hal yang janggal atau membuat pelatihan pengandaian yang tak masuk akal, melebih-lebihkan suatu gaya, dan lainnya), berlatih praktis tidak menyalahkan tapi menunjukkan kelebihan pada teman, dan berlatih memberikan perbaikan pada kesalahan teman secara menyenangkan.

b. Berlatih praktis kepemimpinan melalui membuat ide-ide didalam kelompok, berlatih praktis mengkoordinir teman secara menyenangkan, berlatih membicarakan kebaikan teman daripada keburukan teman, dan berlatih memimpin kelompok.

c. Bimbingan khusus pada siswa yang belum mampu mengetahui minat bakat dan mengikutkan siswa pada kegiatan guru diluar jam sekolah.

d.Secara langsung menunjukkan pada siswa tentang kasus-kasus buruk secara riil yang dampaknya cukup menimbulkan kengerian pada siswa, sehingga siswa enggan mengulang berbuat buruk seperti berani pada guru dan berbuat kasar pada teman.

e. Memotivasi siswa untuk berani melangkah setelah mengatur waktu untuk mendapatkan income tambahan daripada melakukan pemerasan, serta mengkondisikan terjadinya kerjasama bisnis antar siswa yang kurang mampu dalam membentuk kemandirian hidup

\section{Pelaksanaan Siklus II}

Tindakan pada penelitian ini sama demgan siklus I, hanya ditambah dengan poin-poin perbaikan sebagaimana dalam perencanaan siklus II sebagai berikut:

\section{a) Jalur bimbingan melalui pembelajaran didalam kelas.}

Jalur bimbingan melalui pembelajaran BK didalam kelas dilaksanakan yang terkait dengan

hal-hal yang bersifat konseptual dan dasar-dasar pengetahuan yang penting bagi siswa. Jalur yang ditempuh melalui bimbingan dalam kelas ini diantaranya adalah:

a. Bimbingan motivasi untuk menumbuhkan harapan-harapan pada siswa terkait dengan bersikap baik, dekat dengan guru, komunikatif, dan sikap berprestasi sehingga siswa akan lebih diakui keberadaannya baik oleh guru, sekolah, maupun rekan sekolah sesame dan lawan jenis, dimana tujuan dari bimbingan ini adalah memahamkan pada siswa untuk mendapatkan perhatian dan pengakuan dari guru, yang akan berdampak luas dalam kehidpannya bersosial di sekolah.

b. Menunjukkan video-video dampak buruk dari perbuatan yang tidak baik, berani pada guru ataupun orang tua. 
c. Menunjukkan pada siswa tentang bagaimana cara positif mencari perhatian lawan jenis dengan cara yang tidak melanggar susila yaitu dengan teknik komunikasi (teknik mendengarkan pembicaraan lawan jenis secara empatik, teknik memberi perhatian positif, teknik humor, teknik untuk saling membangun prestasi).

d. Memberikan pelatihan praktis membangun strategi komunikasi, sense of humor, membangun empati, dan pelatihan bersosial secara berkelompok.

e. Memberi bimbingan bahwa kebutuhan biologis akan dapat dicapai pada waktunya nanti, dan memberi pengetahuan tentang dampak buruk dalam berlebihan memenhi kebutuhan biologis, yang diikuti dengan bimbingan untuk memberi motivasi siswa untuk menemukan kegiatan positif seperti melalui music atau olah raga.

f. Memberi bimbingan tentang membiasakan memandang dari kacamata pihak lain, sehingga siswa memahami dampak perbuatannya dimata orang lain.

g. Memberikan bimbingan strategi merebut empati orang lain sehingga power yang dimilikinya dengan sendirinya akan muncul, melalui strategi membangun gagasan dalam kelompok, mengkoordinir teman kelompok, dan berlaku menyenangkan serta melindungi anggota kelompok sehingga powernya sangat diakui kelompok, dalam kegiatan positif.

h. Pelatihan praktis kepemimpinan secara berkelompok.

i. Memberi bimbingan tentang bagaimana langkah yang paling tepat untuk mendapat perhatian melalui strategi praktis berkomunikasi (mendengarkan pembicaraan, empatik, humor, gemar memberikan alternatif solusi pada masalah orang lain), strategi prestasi pada bidang tertentu, strategi bersosial.

j. Memberi bimbingan tentang arti penting dan manfaat tata tertib sekolah.

k. Memberi bimbingan tentang bagaimana cara agar siswa mendapat pengakuan kedewasaan dengan cara positif, seperti dengan berperan dan menunjukkan kemampuan dalam bidang kelompok humoris, olah raga, musik, atau hal positif lainnya.

l. Memberikan bimbingan tentang dampak buruk yang luas akibat berani pada orang lain termasuk guru.

$\mathrm{m}$. Memberikan bimbingan tentang cara memperoleh simpatik dari guru sehingga rasa benci berubah menjadi suka setelah mendapat simpatik dari guru, melalui sikap berani tampil didepan kelas, aktif dalam kegiatan diskusi kelas, aktif berkomunikasi dengan guru didalam dan diluar sekolah

n. Memberikan bimbingan tentang bagaimana cara menunjukkan eksistensi dan keunggulan kelompok dengan cara yang inovatif dan dalam hal yang positif, seperti inovasi coretan dinding pada papan majalah dinding, membangun kreasi desain pada papan kreasi siswa sehingga pengakuan positif akan bermunculan akibat coretan yang positif.

o. Memberikan bimbingan resolusi konflik yang mengarah pada win-win solution (menang sama menang), seperti dengan trik bagaimana memprediksi kepentingan lawan sehingga bertindak membangkitkan amarah, memberikan solusi atas kepentingan lawan, mengakomodir kepentingan bersama, dan membangun kedekatan.

p. Menunjukkan cara inovatif dala menunjukkan eksistensi diri dan kelompok seperti bertanding skill secara fair.

q. Memberikan harapan pada masa depan dan memikirkan dampak buruk pada masa depan anak melalui studi kasus penggunaan miras dan narkoba.

r. Menunjukkan trik dan tips menghindari penggunaan narkoba.

s. Memberikan bimbingan tentang analisis kebutuhan melalui skala prioritas pemebuhan kebutuhan untuk mengendalikan kebutuhan yang kurang baik atau berat terpenuhi.

t. Memberikan bimbingan teknik komunikasi untuk membujuk teman dalam hal yang baik sehingga kebutuhan positif siswa dapat terpenuhi, yaitu dengan menguraikan hal-hal yang 
akan diperoleh teman apabia mengikuti ajakan positifnya, menguraikan detil tujuan, dan memberikan alternative tindakan

\section{b) Jalur bimbingan khusus di ruangan BK}

Jalur ini bukan jalur untuk menakut-nakuti atau memarhi siswa, akan tetapi justru lebih ditekankan pada jalur pemberian motivasi atau dorongan khusus, sehingga keinginan siswa untuk meninggalkan delinquency akan muncul dengan tumbuhnya harapan positif. Tindakan pada jalur ini dilakukan seiring dengan munculnya kasus, yang mana tindakan ini juga dapat berupa pengulangan dari jalur bimbingan dalam kelas yang lebih diperdalam di ruangan khusus, diantaranya adalah:

a. Guru menumbuhkan harapan-harapan pada siswa terkait dengan bersikap baik, dekat dengan guru, komunikatif, dan sikap berprestasi sehingga siswa akan lebih diakui keberadaannya baik oleh guru, sekolah, maupun rekan sekolah sesame dan lawan jenis.

b. Guru mengupayakan pertemuan antara siswa dengan guru terkait dan guru BK dalam media permainan / olah raga bersama, yang ditindak lanjuti dengan realisasi diluar jam sekolah.

c. Bimbingan khusus untuk mengidentifikasi dan menemukan minat bakat siswa sampai pada merumuskan minat bakat yang paling mungkin untuk dikembangkan.

d. Mengaktifkan siswa pada bidang atau organisasi yang disenangi seperti olah raga serta memotivasi berprestasi untuk mendapatkan pengakuan akan eksistensi diri.

e. Memberikan tantangan pada kelompok siswa untuk memenangkan kompetisi olah raga melawan para guru.

f. Bekerjasama dengan guru agama memberikan bimbingan larangan tindak asusila dalam agama.

g. Memberi motivasi siswa untuk menemukan kegiatan positif seperti melalui music atau olah raga.

h. Membantu siswa terlibat dalam kegiatan ekstra kurikuler di sekolah pada bidang yang disenangi.

i. Membentuk kelompok siswa dan menyelenggarakan pelatihan kepemimpinan dalam kelompok untuk mengembangkan power melalui pelatihan kepemimpinan positif.

j. Memberi motivasi pada siswa bahwa siswa berhak memperoleh penghargaan melalui cara yang positif, lebih dari apa yang diharapkan.

k. Memberikan alternative pada siswa untuk mencoba-coba hal yang positif dan melibatkan secara langsung dalam kegiatan di sekolah.

l. Mengupayakan terjadinya interaksi guru dan siswa terkait diluar sekolah melalui permainan bulu tangkis atau lainnya, yang diimplementasikan diluar jam sekolah.

m. Memberikan bimbingan resolusi konflik yang mengarah pada win-win solution (menang sama menang), seperti dengan trik bagaimana memprediksi kepentingan lawan sehingga bertindak membangkitkan amarah, memberikan solusi atas kepentingan lawan, mengakomodir kepentingan bersama, dan membangun kedekatan.

n. Menunjukkan cara inovatif dala menunjukkan eksistensi diri dan kelompok seperti bertanding skill secara fair.

o. Memberikan bimbingan cara-cara mendapatkan penghasilan tambahan secara terbatas disela-sela jam sekolah.

p. Memberikan bimbingan tentang peluang mendapatkan beasiswa.

q. Memberikan bimbingan tentang analisis kebutuhan melalui skala prioritas pemebuhan kebutuhan untuk mengendalikan kebutuhan yang kurang baik atau berat terpenuhi. 
r. Memberikan bimbingan teknik komunikasi untuk membujuk teman dalam hal yang baik sehingga kebutuhan positif siswa dapat terpenuhi, yaitu dengan menguraikan hal-hal yang akan diperoleh teman apabia mengikuti ajakan positifnya, menguraikan detil tujuan, dan memberikan alternative tindakan.

s. Secara khusus di ruangan BK Membentuk kelompok ushaa pada siswa-siswa nakal yang kurang mampu secara ekonomi untuk mengatur waktu dan berlatih usaha mandiri tanpa merugikan jam sekolah.

Tabel 4. Hasil observasi Bentuk-Bentuk Kenakalan Remaja Pada Siklus II

\begin{tabular}{|c|c|c|c|}
\hline No & Bentuk Kenakalan & $\begin{array}{c}\text { Rata-Rata } \\
\text { Frekwensi } \\
\text { Ditemuinya } \\
\text { Kejadian } \\
\text { perbulan }\end{array}$ & Skor \\
\hline \multicolumn{4}{|c|}{ Kenakalan Berupa Pelanggaran Norma Kesusilaan dan Tata Tertib Sekolah } \\
\hline 1 & Membolos dan kabur dari jam pelajaran & 0 kali & 0 \\
\hline 2 & $\begin{array}{l}\text { Berkelompok dan berlaku iseng pada lawan jenis } \\
\text { seperti mencolek. }\end{array}$ & 1 kali & 1 \\
\hline 3 & $\begin{array}{l}\text { Berkelompok dan melakukan aktivitas yang tidak } \\
\text { tertib (ribut, gaduh, menimbulkan ketakutan) }\end{array}$ & 2 kali & 1 \\
\hline 4 & $\begin{array}{l}\text { Melihat hal-hal yang bersifat cabul melalui } \\
\text { handphone dan lainnya }\end{array}$ & 2 kali & 1 \\
\hline 5 & $\begin{array}{l}\text { Penggunaan bahasa kasar yang melanggar kesusilaan } \\
\text { pada teman sekolah. }\end{array}$ & 3 kali & 2 \\
\hline 6 & $\begin{array}{l}\text { Berpakaian tidak rapi sebagaimana tata tertib yang } \\
\text { ditentukan. }\end{array}$ & 2 kali & 2 \\
\hline 7 & Merokok di lingkungan sekolah. & 2 kali & 1 \\
\hline 8 & $\begin{array}{l}\text { Berani pada guru saat proses pembelajaran seperti } \\
\text { menentang perintah guru atau menggunakan bahasa } \\
\text { yang tidak sopan. }\end{array}$ & 0 kali & 0 \\
\hline 9 & Aksi corat-coret dinding sekolah & 0 kali & 0 \\
\hline 10 & Menyontek saat ulangan & 2 kali & 1 \\
\hline \multicolumn{4}{|c|}{ Kenakalan Berupa Pelanggaran Hukum } \\
\hline 1 & Perkelahian didalam ataupun diluar sekolah & 0 kali & 0 \\
\hline \multirow[t]{2}{*}{2} & Miras dan Narkoba & 0 kali & 0 \\
\hline & $\begin{array}{l}\text { Pelecehan sexual tingkat ringan yang belum sampai } \\
\text { pada tahap pemerkosaan }\end{array}$ & 0 kali & 0 \\
\hline 3 & Tindak pemerasan & 1 kali & 1 \\
\hline 4 & $\begin{array}{l}\text { Tindak pemaksaan yang berupa memaksa teman } \\
\text { untuk mengikuti kehendaknya dengan cara } \\
\text { mengancam }\end{array}$ & 0 kali & 0 \\
\hline 5 & Tindak penipuan & 0 kali & 0 \\
\hline \multicolumn{2}{|c|}{ Rata-Rata } & $\begin{array}{c}1 \text { kali } \\
\text { (atau } 2 \text { kali) }\end{array}$ & 1 \\
\hline
\end{tabular}

Hasil observasi tersebut menunjukkan penurunan rata-rata frekswensi kenakalan remaja pada siswa, yaitu $1 \times$ kejadian per bulan.

Refleksi pada siklus II atau akhir siklus berupa:

1. Perlunya mempertahankan tindakan-tindakan yang telah baik pada siklus II dalam melaksanakan kasus-kasus kenakalan remaja pada siswa. 
2. Menindaklanjuti pembelajaran kemandirian bagi siswa nakal yang kurang mampu secara ekonomi dengan berlatih mengelola waktu dan membangun pelatihan usaha mandiri sehingga anak tidak melakukan pemerasan.

3. Perlunya melibatkan psikolog untuk pembelajaran potensi siswa dan penanggulangan gejala kenakalan siswa.

\section{SIMPULAN DAN SARAN}

\section{A. Simpulan}

Berdasarkan atas hasil penelitian, dapat dirumuskan kesimpulan hasil penelitian yaitu tindakan yang dikembangkan dengan pendekatan Meminimalisir Kenakalan Siswa Melalui Identifikasi Sebab-Sebab Pemicu Kemunculannya dilakukan dengan:

1) Upaya menumbuhkan harapan akan dampak baik jangka pendek dan panjang jika siswa bersikap baik, dekat dengan guru, serta mampu berkomunikasi dengan gaya yang memikat, serta mampu berprestasi.

2) Bimbingan cara mencari perhatian lawan jenis dan rekan sekolah dengan strategi komunikasi yang empatik dan bukan dengan cara pelanggaran norma kesusilaan.

3) Strategi bekerjasama dengan guru agama untuk menanamkan nilai-nilai religious dengan cara diskusi ringan antara siswa-guru (bukan menceramahi).

4) Mengkondisikan terpenuhinya kebutuhan eksistensi diri serta memberikan kesenangan, dengan mengaktifkan siswa pada organisasi-organisasi ekstrakurikuler yang disenangi seperti bidang olah raga, music, dan lainnya.

5) Memberikan bimbingan analisis dampak dari suatu tindakan buruk, dampak dari mengumbar hasrat biologis yang belum waktunya dipenuhi, dan dilanjutkan dengan bimbingan strategi mengalihkan perhatian dari kebutuhan biologis dengan kegiatan positif.

6) Memberikan bimbingan kepemimpinan untuk mendapatkan power kekuasaan, yang dengan penugasan pada siswa untuk masuk pada kelompok kegiatan positif seperti music, olah raga, atau lainnya.

\section{B. Saran}

Berdasarkan atas hasil-hasil penelitian, dibuat saran-saran sebagai berikut:

1) Sekolah perlu mengupayakan terjadinya bimbingan psikologis untuk memberikan pengalaman dan pengetahuan pada siswa secara khusus, sehingga siswa yang berada pada kondisi remaja yang masih labil dapat menemukan identitas dirinya secara lebih baik.

2) Perlu dilaksnakaan penelitian lanjutan yang lebih detil tentang upaya penanggulangan kenakalan remaja pada siswa sehingga dapat diuraikan lebih mendalam tentang strategi menangani kenakalan remaja pada anak secara lebih baik.

\section{DAFTAR RUJUKAN}

Arikunto, Suharsimi. 2006. Prosedur Penelitian Suatu Pendekatan Praktik. Jakarta: Rineka Cipta.

Dimyati dan Mudjijono. 1999. Belajar dan Pembelajaran. Jakarta: Rineka Cipta.

Elviana, F., Fakar, A., \& Bulan, A. 2020. Pendidikan Karakter dan Pengajaran dengan Metode Demonstrasi untuk Kemajuan Belajar Generasi Millenial. Prosiding Seminar Nasional IPPeMas 2020, 1(1), 702-706. Sumbawa: LPPM Universitas Samawa.

Faidah, C. N. 2018. Dekonstruksi Sastra Anak: Mengubah Paradigma Kekerasan dan Seksualitas pada Karya Sastra Anak Indonesia. Jurnal Kredo, 2(1), 126-139.

Fathirma'ruf, F., \& M. Said, B. (2020). Pengembangan Perangkat Pembelajaran Konstruktivistik Model Teaching with Analogies (TWA) pada Mata Kuliah Database Management System 
(DBMS) untuk Meningkatkan Kemampuan Berpikir Kreatif Mahasiwa.Jurnal Teknologi Informasi dan Ilmu Komputer, 7(5), 1051-1060. doi:http://dx.doi.org/10.25126/jtiik.2020752388

Halian, Ahmad J. 2008. Bimbingan Konseling. Jakarta: Gramedia

Hamalik, Oemar. 2009. Proses Belajar Mengajar. Jakarta: PT. Bumi Aksara.

Hamdani. 2011. Strategi Beajar Mengajar. Bandung:

Johanna, P. Hansen. 1995. Psikologi Anak dan Remaja. Jakarta: Gramedia

Junaini, E., Agustina, E., \& Canrhas, A. 2017. Analisis Nilai Pendidikan Karakter Pada Cerita Rakyat Seluma. Jurnal Korpus, 1(1), 39-43.

Makmun, H.A. Syamsudin. 2007. Psikologi Kependidikan. Jakarta: Rineka Cipta.

Milles, J dan Huberman, Paul. 2001. Metode Penelitian Kualitatif. Jakarta: UI

Moeloeng, J. Lexy. 2009. Penelitian Kualitatif. Bandung: Remaja Rosdakarya.

Siagian, P. Sondang. 2001. Manajemen Sumberdaya Manusia. Jakarta: Rineka Cipta

Sudarsono, 2004. Kenakalan Remaja, Cetakan Keempat. Jakarta: PT.Rineka Cipta

Undang-Undang No 20 Tahun 2003 Tentang Sistem Pendidikan Nasional. Jakarta: Departemen Pendidikan Nasional 